\title{
Projected configuration of a coal-fired district heating source on the basis of comparative technical-economical optimization analysis
}

\author{
Mariusz Tańczuk ${ }^{1,2 *}$, Wojciech Radziewicz ${ }^{2,3}$, Eligiusz Olszewski ${ }^{2}$, and Janusz Skorek $^{4}$ \\ ${ }^{1}$ Opole University of Technology, Department of Environmental Engineering, ul. St. Mikołajczyka 5, 45-271 Opole, Poland \\ ${ }^{2}$ Energetyka Cieplna Opolszczyzny SA, ul. Harcerska 15, 45-118 Opole, Poland \\ ${ }^{3}$ Opole University of Technology, Department of Power Plant, Diagnostics and Computer Engineering, ul. Prószkowska 76, 45-758 \\ Opole, Poland \\ ${ }^{4}$ Silesian University of Technology, Institute of Thermal Technology, ul. Konarskiego 22, 44-100 Gliwice, Poland
}

\begin{abstract}
District heating technologies should be efficient, effective and environmentally friendly. The majority of the communal heating systems in Poland produce district hot water in coal-fired boilers. A large number of them are considerably worn out, low-efficient in the summer time and will not comply with forthcoming regulations. One of the possible solution for such plants is repowering with new CHP systems or new boilers fuelled with fuels alternative to coal. Optimisation analysis of the target configuration of municipal heat generating plant is analysed in the paper. The work concerns repowering the existing conventional heat generating plant according to eight different scenarios of the plant configuration meeting technical and environmental requirements forecasted for the year of 2035. The maximum demand for heat of the system supplied by the plant is $185 \mathrm{MW}$. Taking into account different technical configurations on one side, and different energy and fuel prices on the other side, the comparative cost-benefits analysis of the assumed scenarios has been made. The basic economical index NPV (net present value) has been derived for each analysed scenario and the results have been compared and discussed. It was also claimed that the scenario with CHP based on ICE engines is optimal.
\end{abstract}

\section{Introduction}

Energy and climate strategy of the European Union (EU) bases on three urgently important actions: improving energy efficiency of the processes, applying renewable resources in energy generation and cutting down carbon dioxide $\left(\mathrm{CO}_{2}\right)$ emissions. Many countries have adopted energy policies to achieve such goals as increasing share of renewable resources in final energy generation and applying more efficient technologies based on cogeneration of heat and power (CHP) or trigeneration (CCHP). Despite the current changes in the world energy sector as well as the upcoming strategies for the period 2020-2050 [1], inefficient energy systems, often based on solid fuels, mainly coal, still continue to dominate in the structure of the electricity and heat production systems in certain countries of the world, including countries in Europe [2].

Previous and current actions taken to move the energy sector towards environmental friendly and economical efficient shape has focused on both electricity and heat. Centralized generation and distribution of heat via efficient district heating (DH) systems plays an important role in increasing efficiency of energy systems as a whole and seems to be one of a key components in achieving strategic EU goals.
Improving the district heating systems has become a tendency in Europe since at least 20 years. Nowadays, the projects such as Heat Road Map Europe or STRATEGO (Enhanced Heating and Cooling Plans in EU) set out directions in the field of $\mathrm{DH}$ systems modernization and development. [3]. One of the important proposals for future sustainable cities is, undoubtedly "Fourth generation district heating" (4DH) focusing on deep integration of district heating in such cities. According to [4] future DH systems will be characterized by a wide use of combined heat and power together with the utilisation of heat from waste-to-energy and various industrial surplus heat sources as well as the inclusion of renewables [5] and advanced monitoring systems [6]. Moreover, the expected combination of district heating and cooling (DHC) systems can help with applying aforementioned solutions [7]. DHC systems are already found economically feasible, as justified in [8].

District heating system across Europe are differentiated by the technology, temperature of water and delivery extent as well as by the resources used for heat (and electricity) generation. Compared to other European countries, particularly these located in western and northern part of Europe, the coal is a dominant energy source in Central and East Europe DH

*Corresponding author: m.tanczuk@po.opole.pl 
applications. According to [9] district heating systems supply with heat around $29 \%$ of residential buildings in that region. An interesting and worth attention case is Poland with $41 \%$ share of DH systems [10] and in the same time with coal as a main source of input energy of heat generating plants. The hard coal remains dominant resource for decades, however its share in heat production is expected to go down as stated in long-term forecasts available in [11].

Vast number of DH system around the world, particularly supplied with coal, require or will require smaller or bigger modifications (i.e. retrofitting) to meet new strict environmental and efficiency standards as well as to have their feasibility improved. In [2] authors claim that due to the continuous restrictions in the dust and sulfur dioxide $\left(\mathrm{SO}_{2}\right)$ emissions, the heating industry in Poland faces the necessity of spending whacking expenses of new dedusting and desulfurization installations. The $\mathrm{CO}_{2}$ limitations are also cost-creative and will require modernization of $\mathrm{DH}$ facilities not only in Poland. Eventually, another reason for reconfiguration of the plants and starting necessary investment actions is technical wear of the existing boilers, low-efficient production of heat for network hot water during the offpeak periods and far from optimal configuration of the existing DH sources.

One of the most common DH solutions for managing the current and upcoming conditions is to apply repowering plants with the $\mathrm{CHP}$, usually gas-fired systems. As stated in [12], cogeneration of heat and power technology, compared to separate technologies, always offers the possibility of increasing the efficiency of the energy production and results in a decrease of primary energy use. Energy efficient DH systems also require usage of renewable resources as a measure for giving the positive impact for DH energy efficiency [13]. Regardless of the applied technology of DH plants, energy efficiency of the process should always be high. Optimum efficiency level should, however, result from economic factors. A DH system with an optimally selected and configured source is one, which not only leads to the savings in the use of the primary energy but also has to offer economic benefit.

The further part of this paper presents issues connected with the thermal and economic efficiency of a coal-fired municipal heat generating plant as a source of DH system. The projected configuration has been assumed and the optimization analysis of the plant modernization by installing new units or repowering existing ones, including CHP systems is the subject of the paper.

The aim of presented work is to find optimal DH source configuration as a retrofitting solution for coalfired municipal heat generating plant.

\section{System description}

The investigation concerns repowering the existing conventional heat generating plant according to eight different scenarios of the plant configuration meeting technical and environmental requirements forecasted for the year of 2035. The existing plant is a heat source for high temperature municipal district heating system with the maximum demand for heat reaching $185 \mathrm{MW}$. The hot water of nominal pressure $p_{n}=1.6 \mathrm{MPa}$ and nominal (maximum) supply temperature $t_{s, n}=150{ }^{\circ} \mathrm{C}$ is a heat carrier in the system.

The plant consists of the following heat generating units:

- one pulverized hard coal-fired water boiler PCB (labelled as WP120) with the nominal heat capacity $125 \mathrm{MW}$,

- two hard coal stoker-fired water boilers SCB (labelled as WR25 no. 1 and. 2) with the nominal heat capacity $33 \mathrm{MW}$ each,

- high-efficient cogeneration unit based on a gas turbine unit GTU fired with natural gas of a nominal electric capacity 7.4 MW and integrated with a heat recovery boiler HRB of a nominal heat capacity $14.7 \mathrm{MW}$,

- high efficient cogeneration unit based on a steam turbine STU supplied with hard coal stoker-fired steam boiler SSCB (labelled as OR50) of a steam capacity $50 \mathrm{t} / \mathrm{h}$.

The STU cogeneration unit is integrated with a steam-water heat exchanger and reaches the nominal thermal capacity $29 \mathrm{MW}$ and nominal electric capacity 10.7 MW. In the heat-only operation mode, thermal capacity increases up to $40 \mathrm{MW}$. Apart from the described units, there is also additional production facility installed in the plant:

- one pulverized hard coal-fired water boiler PCB (labelled as WR40) - of $40 \mathrm{MW}$ of thermal capacity remaining permanently disconnected from the plant infrastructure,

- one gas boiler of $25 \mathrm{MW}$ of thermal capacity installed as a peak-load unit.

The schematic diagram of the existing plant is shown in Fig. 1. The total installed heat capacity of the analyzed plant reaches almost $260 \mathrm{MW}$ (without $40 \mathrm{MW}$ of disconnected boiler). The total electricity power output equals to $18.1 \mathrm{MW}$.

Table 1 presents main performance data of the plant supplying district heating system under investigation.

Table 1. Performance data of the DH system - current state.

\begin{tabular}{|c|c|r|}
\hline \multicolumn{2}{|c|}{ Parameter } & \multicolumn{1}{c|}{ Value } \\
\hline Annual heat production & $Q_{D H}$ & $1582500 \mathrm{GJ}$ \\
\hline Annual electricity production & $E_{e l}$ & $106000 \mathrm{MWh}$ \\
\hline Annual heat sale & $S_{D H}$ & $1369700 \mathrm{GJ}$ \\
\hline Delivery heat losses & $Q_{L}$ & $212800 \mathrm{GJ}$ \\
\hline $\begin{array}{c}\text { Annual heat production in } \\
\text { cogeneration }\end{array}$ & $Q_{C H P}$ & $935500 \mathrm{GJ}$ \\
\hline Demand for chemical energy & $E_{c h}$ & $2298900 \mathrm{GJ}$ \\
\hline $\begin{array}{c}\text { Demand for chemical energy for } \\
\text { electricity production }\end{array}$ & $E_{c h, e l}$ & $455000 \mathrm{GJ}$ \\
\hline $\begin{array}{c}\text { Demand for chemical energy for } \\
\text { heat production }\end{array}$ & $E_{c h, h}$ & $1843900 \mathrm{GJ}$ \\
\hline
\end{tabular}


The load duration curve of the district heating system supplied by the plant is presented in the Figure 2. As it can be seen, the plant remains under operation during the whole year time supplying city DH system with heat in order to provide central heating of residential buildings (in the heating season) and domestic hot water (in the season and off-season). The difference between maximum demand in the winter time that equals 185 MW and rather constant demand during off-season (around $15 \mathrm{MW}$ ) is significant and worth noting. A much lower demand for heat by $\mathrm{DH}$ in the summer time often results in reduced boiler load and, consequently, can lead to low efficiency of the plant. Such inconvenience occurs with non-optimized plants with oversized units or
The considered system has already been retrofitted by building two cogeneration units: gaseous unit GTU with gas turbine fed with natural gas and the unit based on a steam turbine STU supplied by steam generated in a stoker-fired boiler fuelled with hard coal. As it can be seen in the table 1 , the share of heat produced in cogeneration process reaches almost $60 \%$. Installing CHP facilities was the first stage of repowering and thus the plant requires further modification to meet new requirements and up-coming regulations. Accordingly, different scenarios of district heating plant configuration meeting technical and environmental requirements has been assumed and presented in the further part of the paper.

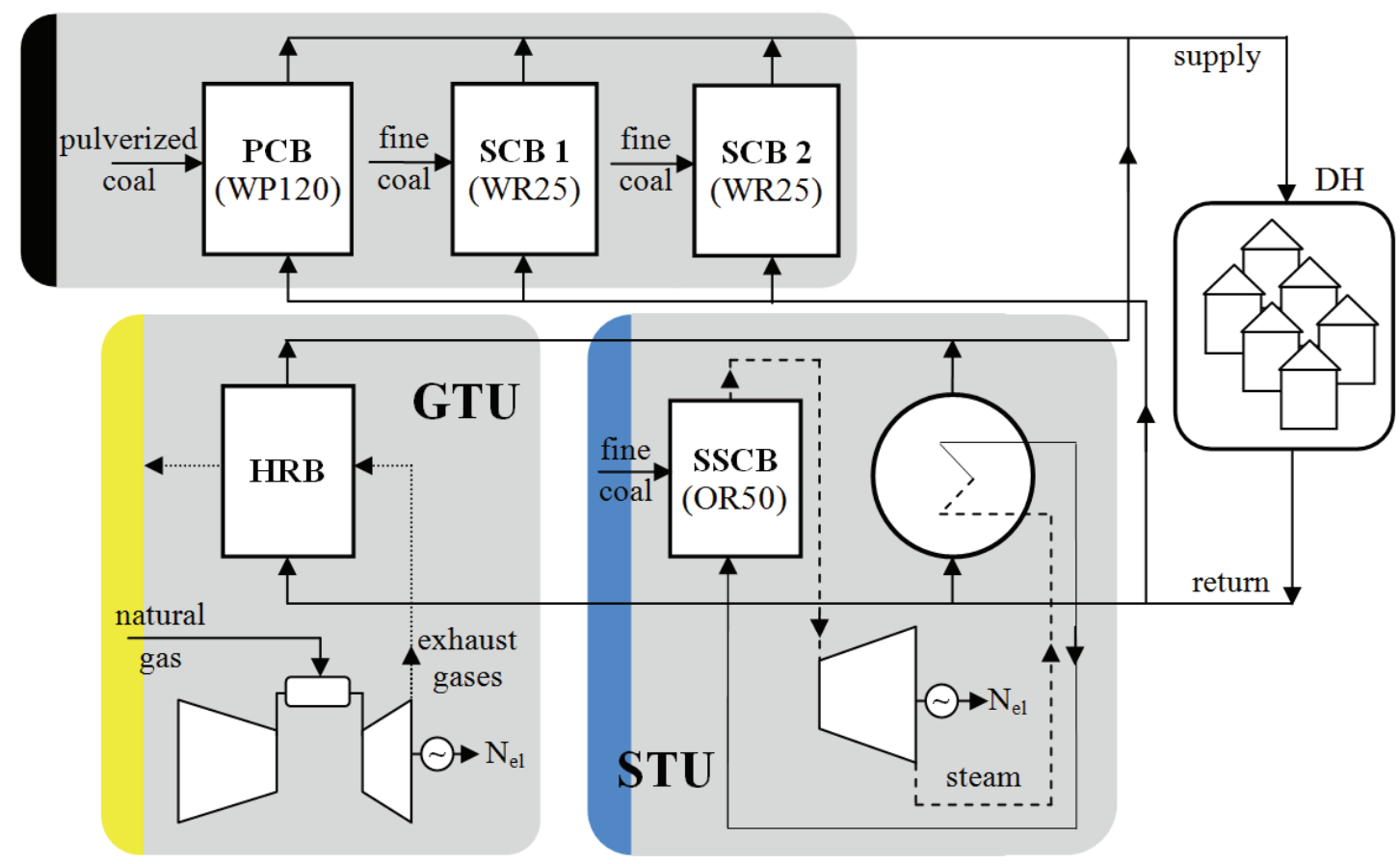

Fig. 1. Schematic diagram of the current configuration of analyzed DH plant.

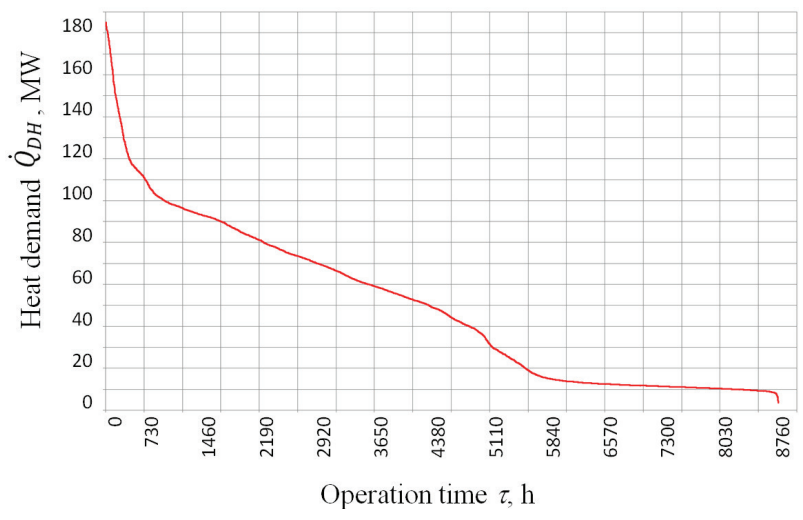

Fig. 2. The load duration curve of the analyzed district heating system.

not enough number of units. One of the solution for drawback of off-season efficiency decrease is installing properly sized CHP unit operated at the base load during the possible longest time a year.

\section{Methods and input data}

The research goal is to investigate technical and economic feasibility of DH plant configured according to assumed scenarios. For the analysed type of modernization of heat source of $\mathrm{DH}$, the analysis consists of thermodynamic and economic evaluation linked by a direct correlation. The economic indexes calculated within the analysis are a measure made of a number of parameters. The majority of them is the function of the thermodynamic quantities resulting from the technical characteristics of equipment as well as configuration and operation of the thermal plant.

\subsection{Thermodynamic evaluation}

The basis for the thermodynamic evaluation was the heat load duration curve (Fig. 2) given as an input data for the 
analysis. The energy balance calculations were conducted for each eight investigated configuration scenarios where assumed units of a given size and given efficiency were composed in heat generating DH plant. Analysis has been carried out with use of hourly optimization method. Similar approach of hour by hour simulation was applied in the research dedicated to the polish municipal DH case in [2] as well as in the case study of city Zagreb presented in [14].

Table 2 presents main design parameters of the units used for configuring the plant according to the following scenarios:

- scenario $\mathbf{S 1}$ - based on the current configuration of the plant (Fig. 1) with no retrofitting actions, taking into account only the necessary maintenance and modernization work due to technical condition of units and environmental restrictions (necessity of construction of flue gas desulphurisation and denitrification),

- scenario S2 - existing configuration of the plant extended by the additional cogeneration unit with biomass steam boiler $\mathrm{BB}$ and extraction steam turbine (Fig. 3),
- scenario S7 - based on S6 configuration but with ICE unites operated at the base load,

- scenario S8 - based on S6 configuration with GTU unit removed.

On the basis of assumed technical configurations of the plant and in accordance with design parameters of applied units as well as with given load duration curve, hour by hour simulation of plant annual operation has been conducted for each of the scenario. In the result, the annual heat and electricity production can be derived with use of the following formulas:

$$
Q_{u_{i}}=\int_{\tau=0}^{\tau=8760}\left(\dot{Q}_{u_{i}}\right) \mathrm{d} \tau
$$

where $Q_{\mathrm{u}_{\mathrm{i}}}$ is the annaul heat production by the particular unit $i, \dot{\mathrm{Q}}_{\mathrm{u}_{\mathrm{i}}}$ is the current heat capacity of the unit $I$ of 5 ICE-based gaseous units (Fig. 4), with steam turbine unit STU operated at the base load, provided by the simulation procedure, $\tau$ - time, in hours

$$
N_{e l, u_{i}}=\int_{\tau=0}^{\tau=8760}\left(\dot{N}_{e l, u_{i}}\right) \mathrm{d} \tau
$$

Table 2. Main design parameters of the units used for plant configuration.

\begin{tabular}{|c|l|c|c|c|c|}
\hline No. & \multicolumn{1}{|c|}{ Unit } & $\begin{array}{c}\text { Max./min. } \\
\text { thermal output, } \\
\text { MW }\end{array}$ & $\begin{array}{c}\text { Nominal electric } \\
\text { output, MW }\end{array}$ & $\begin{array}{c}\text { Nominal } \\
\text { efficiency, } \%\end{array}$ & Remarks \\
\hline 1 & Pulverized coal-fired water boiler PCB & $120 / 55$ & - & 91.5 & existing and operated \\
\hline 2 & Coal stoker-fired water boilers SCB 1 & $33 / 10$ & - & 84.3 & existing and operated \\
\hline 3 & Coal stoker-fired water boilers SCB 2 & $33 / 10$ & - & 84.3 & existing and operated \\
\hline 4 & Coal stoker-fired steam boiler SSCB & $40 / 20$ & - & 85.0 & existing and operated \\
\hline 5 & Back-presure steam turbine STU & - & 10.7 & 29.0 & existing and operated \\
\hline 6 & STU turbine heat exchanger & $29 / 7$ & - & - & existing and operated \\
\hline 7 & Coal stoker-fired water boilers SCB 3 & $40 / 10$ & - & 85.0 & currently disconnected \\
\hline 8 & Gas turbine unit GTU with HRB boiler & $13.5 / 13.5$ & 7.0 & 82.0 & existing and operated \\
\hline 9 & Gas boiler & $25 / 5$ & - & 92.0 & existing, peak-load \\
\hline 10 & Biomass stoker-fired steam boiler BB & $13.7 / 7.6$ & - & 82 & planned \\
\hline 11 & Extraction-condensing steam turbine & - & 6.7 & 31.0 & planned \\
\hline 12 & Pulverized coal-fired water boiler PCB 2 & $81 / 32$ & - & 91.5 & planned \\
\hline 13 & Gaseous ICE-based CHP - 5 units & $5 \times 3.5 / 0.7$ & $5 \times 4.5$ & 83.5 & planned \\
\hline
\end{tabular}

- scenario S3 - based on S2 configuration with GTU unit removed and with steam turbine unit STU operated at the base load,

- scenario S4 - existing configuration of the plant with PCB replaced by currently disconnected repowered SCB3, peak-load gas boiler in use.

- scenario S5 - existing configuration of the plant with PCB replaced by repowered PCB2,

- scenario S6 - existing configuration of the plant with additional CHP block installed on the basis of 5 ICE-based gaseous units (Fig. 4), with steam turbine unit STU operated at the base load, where: $\mathrm{N}_{\mathrm{el}, \mathrm{u}_{\mathrm{i}}}$ is the annaul electricity production of the particular unit $i, \dot{\mathrm{N}}_{\mathrm{el}, \mathrm{u}_{\mathrm{i}}}$ is the current electric power output of the unit $i$ provided by the simulation procedure.

Within the calculation procedure the annual demand for the particular fuels was derived on the basis of nominal efficiency of operated units (Table 2) corrected in line with load characteristics of units. The low heating values were assumed $23 \mathrm{MJ} / \mathrm{kg}$ for hard coal, $36 \mathrm{MJ} / \mathrm{m}^{3}$ for natural gas and $11 \mathrm{MJ} / \mathrm{kg}$ for wooden biomass. The annual carbon dioxide emissions were calculated on the basis of derived fuel quantities and assumed emission factors. The thermodynamic evaluation was the basis for further economic analysis. 


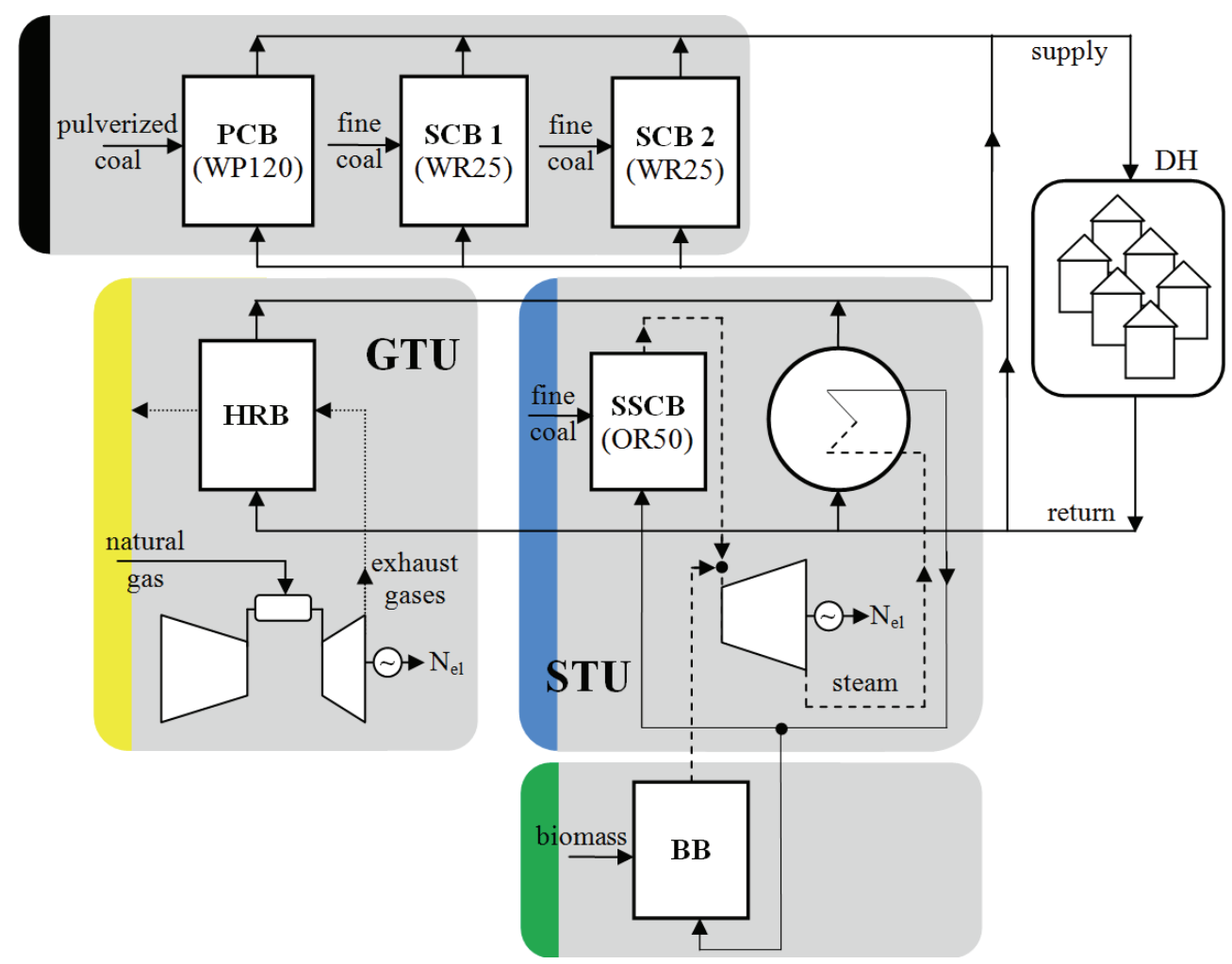

Fig. 3. Schematic diagram of DH plant configuration in scenario $\mathbf{S 2}$.

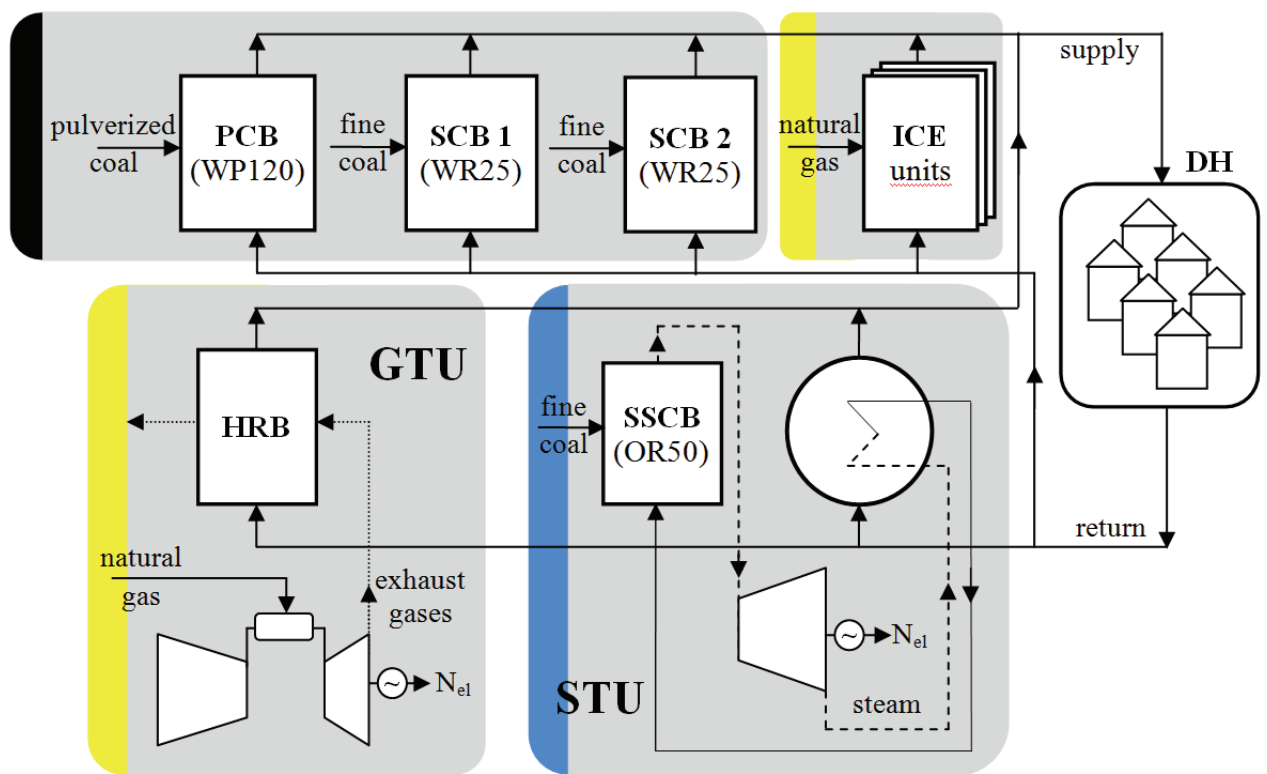

Fig. 4. Schematic diagram of DH plant configuration in scenario $\mathbf{S 6}$.

\subsection{Economic evaluation}

The goal of the optimisation procedure is to find the optimal configuration of the $\mathrm{DH}$ plant regarding the economic feasibility. The economic evaluation bases in this case on discounted method, with Net Present Value (NPV) as the result of the calculations. The chosen method is widely used in cost-effective designs [15], lifetime optimisation [16] and in comparative techno- economic analysis [17]). To determine the NPV index, cash flow parameter $C F$ is used [18], in accordance with the following formula:

$$
N P V(t=N)=-J_{0}+\sum_{t=1}^{N} \frac{C F_{t}}{\left(1+r_{d}\right)^{t}}
$$

where $t$ is the time of operation in years, Nis assumed lifetime of the project expressed in years, $J_{0}$ is the total investment outlays in particular scenario, $C F_{t}-$ annual 
cash flow calculated for each scenario (in EUR), $r_{d}$ - rate of discount.

Annual cash flows were derived with use of the formula (4):

$$
C F_{t}=C_{\tau}+S_{\tau}+T_{\tau}+L
$$

where $C_{t}$ is the annual cost of operation, including fuel costs, maintenance costs, overhauls costs, environmental costs and cost of buying $\mathrm{CO}_{2}$ allowances (European Union Allowances - EUA), $S_{t}$ is the annual sale income (revenues from the sales of heat into the district heating system and revenues due to selling electricity to the grid), $T_{t}$ is the yearly income tax, $L$ is the liquidation value of the project.

Apart from NPV index, the applied method enables to calculate also Net Present Value Ratio (NPVR) indicator which is expressed by the equation:

$$
N P V R=N P V / J_{0}
$$

\subsubsection{Assumptions for economic analysis}

To calculate the value of the annual cash flow CF it was necessary to adopt economic assumptions and additional data. The most important of them are:

- investment outlays for each scenario, specified in Table 3 ,

- overhauls costs for each scenario, specified in Table 3 as total overhauls costs (in 18 years of operations),

- the sales price of heat $p_{h}=9.65 \mathrm{EUR} / \mathrm{GJ}$,

- the sales price of electricity $s_{e l}=35.29$ EUR/MWh [19]

- the price of cogeneration tags (yellow tags) $s_{Y T}=$ 25.88 EUR/MWh [19],

- the price of gaseous cogeneration tags (yellow tags) $s_{Y T}=25.88 \mathrm{EUR} / \mathrm{MWh}$ [19],

- the price of solid fuel cogeneration tags (red tags) $s_{R T}=2.35$ EUR/MWh [19],

- the price of renewable tags (green tags) $p_{G T}=$ 23.53 EUR/MWh [19],

- the price of hard coal $p_{c}=2.81 \mathrm{EUR} / \mathrm{GJ}$,

- the price of biomass $p_{b}=4.94 \mathrm{EUR} / \mathrm{GJ}$,

- the price of natural gas $p_{n g}=5.61 \mathrm{EUR} / \mathrm{GJ}$ [19],

- the price of carbon dioxide $\mathrm{CO}_{2}$ allowances $p_{E U A}=$ $7 \mathrm{EUR} / \mathrm{t} \mathrm{CO}_{2}$.

The further, additional assumptions have been also made, as follows:

- currency exchange rates 4.25 PLN/€,

- operation period of the system: $\mathrm{N}=18$ years,

- priority in the production of electricity for the internal load of the heat generating plant is taken into consideration, excess quantities are sold,

- quantitative data regarding the production and sales in the subsequent years of the operation of the system are derived from the calculations performed in the thermodynamic evaluation,

- discount rate was adopted at the level of $r_{d}=7.5 \%$.
Table 3. Investment outlays $J_{0}$ and cost of overhauls $C_{R}$ for analyzed scenarios.

\begin{tabular}{|c|c|c|}
\hline Scenario & $\begin{array}{c}\text { Outlays, } \\
\text { mln EUR }\end{array}$ & $\begin{array}{c}\text { Entire (18 years) } \\
\text { overhauls, } \\
\text { mln EUR }\end{array}$ \\
\hline S1 & 12.07 & 26.39 \\
\hline S2 & 6.73 & 23.25 \\
\hline S3 & 6.73 & 21.51 \\
\hline S4 & 3.48 & 23.82 \\
\hline S5 & 37.95 & 27.40 \\
\hline S6 & 2.53 & 41.70 \\
\hline S7 & 2.53 & 36.09 \\
\hline S8 & 2.53 & 35.41 \\
\hline
\end{tabular}

\section{Results and discussion}

As a result of the research the hourly simulations for each considered DH plant scenario were conducted. The result operating configurations have been presented on the DH heat load durations curves (Fig. 5). On the basis of simulation the quantitative data needed for further economic analysis were obtained.

Table 5 summarizes the annual demand for fuel in the analyzed configuration cases and the annual quantity of heat and electricity production in each $\mathrm{DH}$ plant scenario. It also contains $\mathrm{CO}_{2}$ emissions calculated during the evaluation. It is worth noting that much less $\mathrm{CO}_{2}$ emissions occur in case of biomass scenarios (S2 and S3). The positive effect of cogeneration should be emphasized for ICE modules scenarios (S6 to S8): in these cases the share of electricity production is significantly larger compared to other configuration alternatives.

Table 4 contains results of economic evaluation. Results have also been presented graphically in the Figure 6.

Table 4. Results of economic analysis conducted for the analyzed scenarios.

\begin{tabular}{|c|c|c|}
\hline Scenario & $\begin{array}{c}\text { NPV, } \\
\text { mln EUR }\end{array}$ & NPVR \\
\hline S1 & 33.65 & 2.79 \\
\hline S2 & 28.71 & 4.27 \\
\hline S3 & 30.59 & 4.55 \\
\hline S4 & 34.12 & 9.80 \\
\hline S5 & 21.88 & 0.58 \\
\hline S6 & 37.64 & 14.88 \\
\hline S7 & 34.59 & 13.67 \\
\hline S8 & 33.64 & 13.30 \\
\hline
\end{tabular}

For easier results comparison, NPV cells in Table 5 have been marked with colors, where red indicates low values (worse feasibility) and green stands for highest ones (best feasibility). 

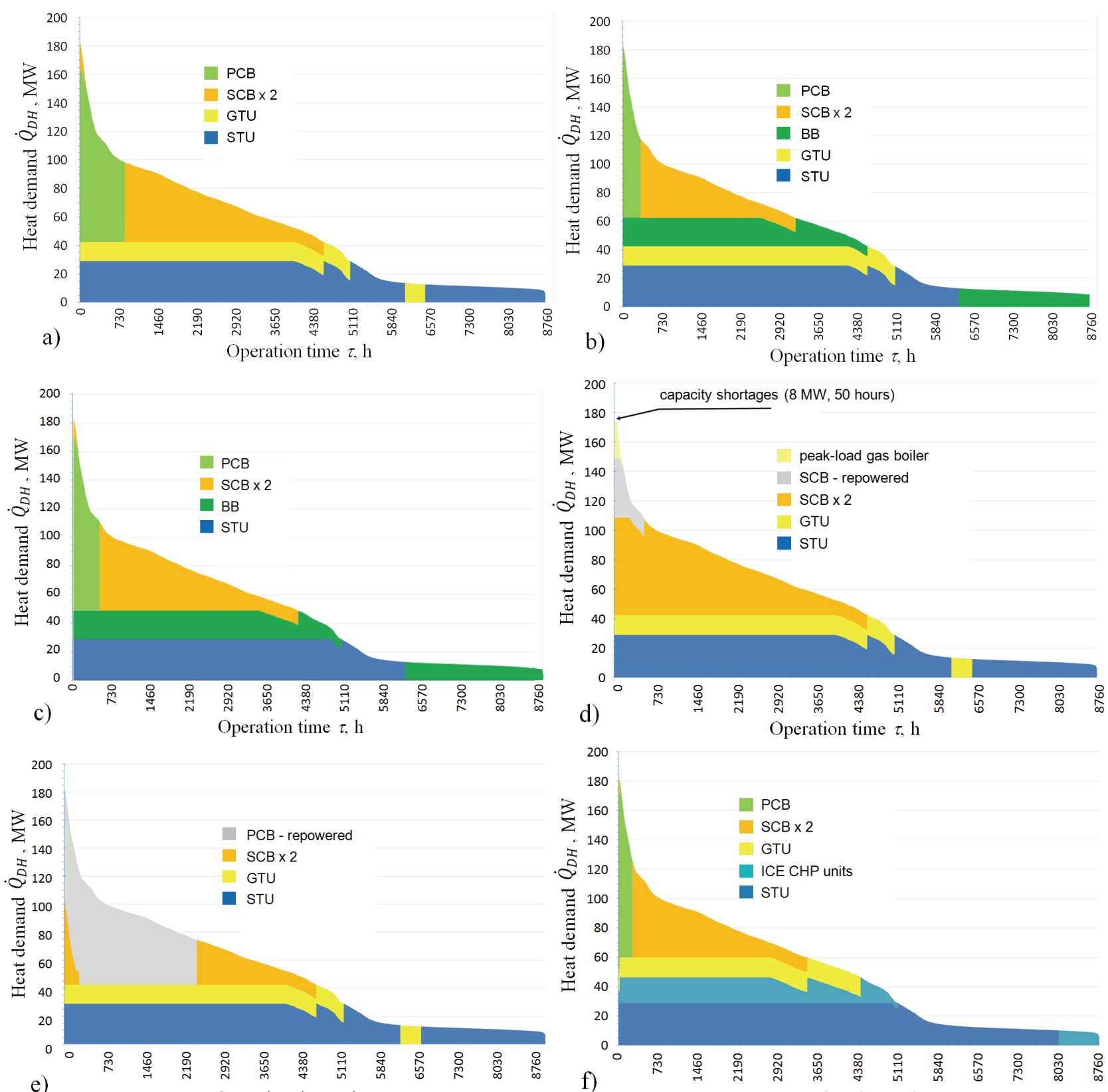

e)

Operation time $\tau, \mathrm{h}$

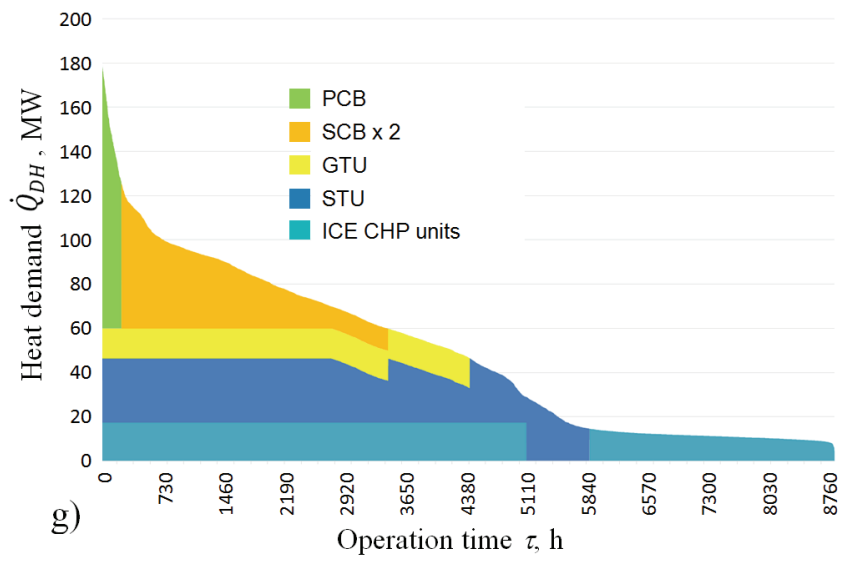

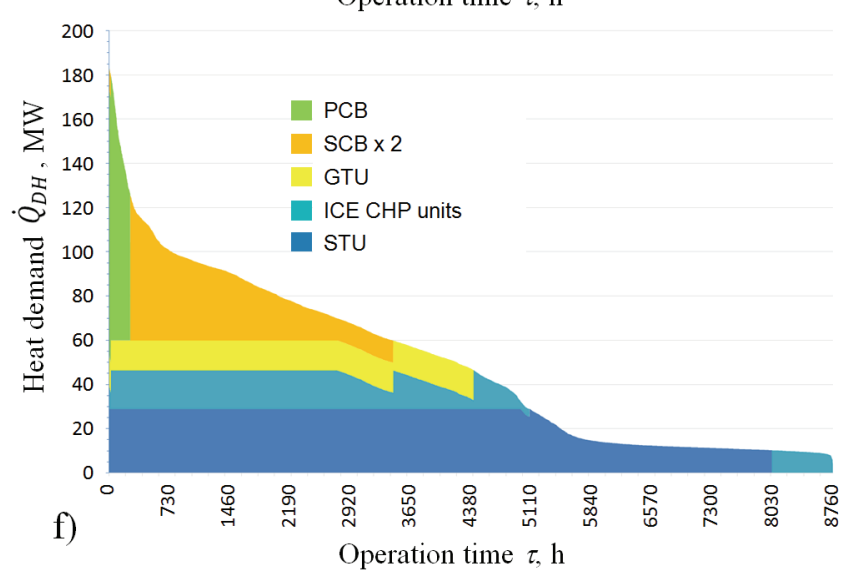

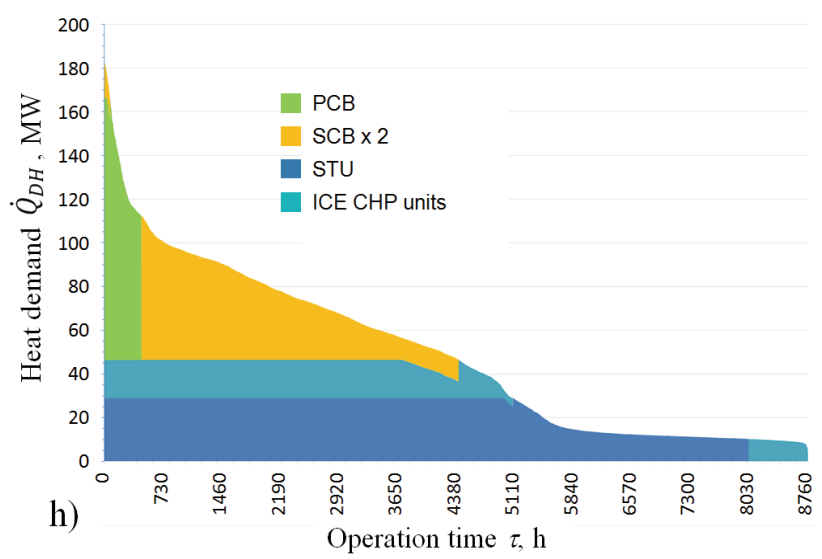

Fig. 5. Results of the simulation of the annual operation of DH plant units conducted for the assumed configuration scenarios: a) S1, b) $\mathrm{S} 2$, c) $\mathrm{S} 3$, d) $\mathrm{S} 4$, e) $\mathrm{S} 5$, f) $\mathrm{S} 6$, g) $\mathrm{S} 7$ and h) $\mathrm{S} 8$. 
Table 5. Quantitative annual operation data of each analyzed plant configuration scenario.

\begin{tabular}{|c|c|c|c|c|c|c|}
\hline Scenario & $\begin{array}{c}\text { Heat generation, } \\
\text { GJ }\end{array}$ & $\begin{array}{c}\text { Electricity } \\
\text { generation, MWh }\end{array}$ & $\begin{array}{c}\text { Demand for coal, } \\
\mathrm{Mg}\end{array}$ & $\begin{array}{c}\text { Demand for } \\
\text { natural gas, } \mathrm{MWh}\end{array}$ & $\begin{array}{c}\text { Demand for } \\
\text { biomass, } \mathrm{Mg}\end{array}$ & $\begin{array}{c}\mathrm{CO}_{2} \text { emission, } \\
\mathrm{Mg}\end{array}$ \\
\hline S1 & 1571317 & 106037 & 78642 & 149397 & 0 & 199102,5 \\
\hline S2 & 1571317 & 102750 & 59135 & 140140 & 44704 & 157302,0 \\
\hline S3 & 1571317 & 68502 & 69385 & 0 & 50333 & 151527,4 \\
\hline S4 & 1570249 & 106037 & 79106 & 152162 & 0 & 200622,2 \\
\hline S5 & 1571317 & 106037 & 77719 & 149397 & 0 & 197087,7 \\
\hline S6 & 1571317 & 200316 & 66569 & 362528 & 0 & 211775,0 \\
\hline S7 & 1571317 & 238109 & 56498 & 484061 & 0 & 212038,0 \\
\hline S8 & 1571317 & 177642 & 76153 & 260957 & 0 & 214102,1 \\
\hline
\end{tabular}

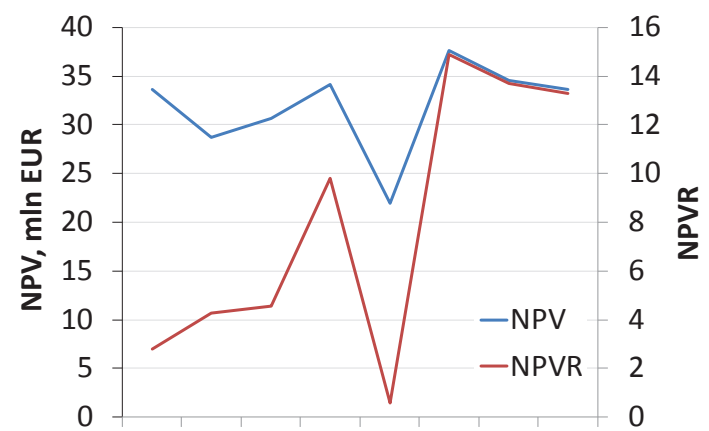

$\begin{array}{llllllll}\text { S1 } & \text { S2 } & \text { S3 } & \text { S4 } & \text { S5 } & \text { S6 } & \text { S7 } & \text { S8 }\end{array}$

Fig. 6. NPV and NPVR indexes derived for analyzed scenarios.

As it can be concluded both from the Table 5 and Figure 6, the highest feasibility, regarding both criteria, NPV and NPVR, occurs for scenarios where CHP units based on natural gas-fired ICE modules are implemented. NPV values in these cases stands between 13 and $15 \mathrm{mln}$ EUR, while for the weakest scenario (S5) hardly exceeds $9 \mathrm{mln}$ EUR. Results gained for S8 case shows that cutting off gas turbine unit from ICE-based scenario lowers profitability of the project: NPV goes down by $1 \mathrm{mln}$ EUR noticed in scenario S7 or even by 4 mln EUR of scenario S6.

It is important to notice here that NPV and NPV-toinvestment ratio trends don't coincide in case of scenario S1, where relatively high investment expenses are involved compared to expected profit.

\subsection{Sensitivity analysis}

In order to evaluate the relation between project value NPV and the key economic parameters, a sensitivity analysis has been performed for analyzed scenarios (Table 6). The procedure of economic evaluation was subsequently repeated for the alternative values of key economic parameters: natural gas and coal prices, electricity selling price, yellow tags price and EUA prices.

The variations of the prices, except for EUA, were assumed as $\pm 10 \%$. In case of EUA two price alternatives were taken into account:

- constant price $7 \mathrm{EUR} / \mathrm{Mg}$ of emitted $\mathrm{CO}_{2}$,

Table 6. Results of sensitivity analysis: NPV in mln EUR.

\begin{tabular}{|c|c|c|c|c|c|c|c|c|c|c|c|}
\hline \multirow[t]{2}{*}{ Scenario } & \multicolumn{2}{|c|}{$\begin{array}{c}\text { EUA } \\
\text { allowanceprices, } \\
\text { EUR/Mg CO }\end{array}$} & \multicolumn{2}{|c|}{ Natural gasprices } & \multicolumn{2}{|c|}{ Hard coalprices } & \multicolumn{2}{|c|}{ Electricityprices } & \multicolumn{3}{|c|}{ Yellow tags prices } \\
\hline & 7 & $\begin{array}{c}\text { Variable } \\
\text { from } 6 \text { to } 23\end{array}$ & $-10 \%$ & $10 \%$ & $-10 \%$ & $10 \%$ & $-10 \%$ & $10 \%$ & $-100 \%$ & $-10 \%$ & $10 \%$ \\
\hline S1 & 31,8 & 21,8 & 34,0 & 29,3 & 31,8 & 31,8 & 28,9 & 34,4 & 23,6 & 30,9 & 32,4 \\
\hline $\mathrm{S} 2$ & 27,1 & 19,1 & 29,6 & 24,9 & 27,1 & 27,1 & 24,7 & 29,8 & 19,3 & 26,4 & 28,0 \\
\hline S3 & 28,9 & 21,3 & 30,0 & 27,8 & 28,9 & 28,9 & 26,7 & 31,1 & 24,2 & 28,4 & 29,3 \\
\hline S4 & 32,2 & 22,2 & 34,7 & 29,8 & 32,2 & 32,2 & 29,6 & 34,9 & 24,2 & 31,3 & 32,9 \\
\hline S5 & 20,7 & 10,9 & 23,1 & 18,4 & 20,7 & 20,7 & 18,0 & 23,3 & 12,7 & 20,0 & 21,6 \\
\hline S6 & 35,6 & 28,4 & 40,9 & 30,4 & 35,6 & 35,6 & 31,1 & 40,2 & 11,1 & 33,1 & 38,0 \\
\hline S7 & 34,7 & 27,3 & 38,9 & 30,4 & 34,7 & 34,7 & 30,4 & 38,7 & 13,6 & 32,4 & 36,7 \\
\hline S8 & 31,8 & 23,6 & 35,1 & 28,4 & 31,8 & 31,8 & 28,2 & 35,3 & 15,6 & 30,2 & 33,6 \\
\hline
\end{tabular}


- variable price in the analyzed time range from 6 EUR in 2018 to 23 EUR in 2035, linearly.

Additionally, case with no support system for cogeneration (yellow certificate prices equal 0) is also analyzed.

Again, for easier results comparison, NPV cells in Table 6 have been marked with colors, where red indicates low feasibility compared to green standing for high one. As the presented values show, scenarios S1 based on current plant configuration and scenarios with ICE cogeneration units are the most sensitive ones. Increase of natural gas prices by $10 \%$ or decrease of electricity prices by $10 \%$ turns ICE-based scenarios less profitable then scenario $\mathrm{S} 1$. Termination of cogeneration support system (no yellow tags and no alternative for that system) makes the configuration with plant retrofitted by ICE units unbeneficial.

\section{Final conclusions}

The presented study is an example of how the proper configuration of the plant supplying district heating system may positively affect the feasibility of the plant operation. Moreover, the analysis shows how to respond to the expected changes in regulations and environmental requirements to preserve the best possible economic results of the plant.

The calculations conducted for the basic economic assumptions showed higher profitability of the cases with natural gas-fired ICE cogeneration modules installed in the plant. However, the sensitivity analysis shows possibility of changing the results of economic analysis so the ICE cases turn into worse configuration option and the current, coal-based facility stays most profitable. It can be also concluded from the analysis that economic results of operating retrofitting municipal district heating plant results from the $\mathrm{CO}_{2}$ allowances prices. Having that in mind, the biomass-fuelled units may give the positive input for the project feasibility.

Accordingly, the following final conclusions can be derived from the undertaken analysis:

- projecting the configuration of the district heating plant requires good prediction on electricity and fuels' prices,

- configuration of the system should always be preceded by thermal and economic optimization,

- retrofitting coal-based DH plant by the cogeneration units fuelled with natural gas may be the solution for on-going changes in environmental and energy efficiency regulations,

- implementation of the biomass district heating facilities in coal-based DH systems can improve feasibility under expected legislative conditions,

- however, if the biomass is expected to get the better of natural gas oriented configurations it requires appropriate mechanisms.

\section{Acknowledgement}

The authors would like to thank the ECO SA - Heat Engineering Company engineers for the cooperation and for the access to operational data of heat generating district heating plant. The authors also gratefully acknowledge the possibility of using the design data of analyzed unites to the ECO SA company.

\section{References}

1. European Commission, "A roadmap for moving to a competitive low carbon economy in 2050," Brussels, 2011.

2. M. Tańczuk, J. Skorek, P. Bargiel, Energy Convers. Manage. 149 (2017)

3. Y. Dou et al. Resour. Conserv. Recycl., (2016), http://dx.doi.org/10.1016/ j.resconrec.2016.03.006. In Press

4. H. Lund, S. Werner, R. Wiltshire, S. Svendsen, J. E. Thorsen, F. Hvelplund and B. V. Mathiesen, Energy, 68 (2014)

5. N. Duić N, M.A. Rosen, Energy Convers. Manage. 87 (2014)

6. S. Anweiler, D. Piwowarski, J.Clean.Prod. 155 (2017).

7. A. Lake, B. Rezaie, S. Beyerlein, Renewable Sustainable Energy Rev. 67 (2017)

8. M. Ameri, Z. Besharati, Energy Build. 110 (2016)

9. Intelligent Energy Europe Programme. Energy Efficiency Trends and Policies in the EU an analysis based on the ODYSSEE and MURE databases (2015)

10. Euroheat \& Power, http://euroheat.org, 2017 [accessed 15 May 2017]

11. District Heating and Cooling Country by Country. 2015 Survey. Euroheat \& Power.

12. M. Badami, M. Mura, P. Campanile, F. Anzioso, Energy 33 (2008)

13. M. Elci, A. Oliva, S. Herkel, K. Klein, A. Ripka, Energy Procedia 70 (2015)

14. M. Pavičević, T. Novosel, T. Pukšec, N. Duić, Energy (2017) https://doi.org/10.1016/j.energy 2017.06.105 (In Press)

15. A. Vlysidis, M. Binns, C. Webb, C.A. Theodoropoulos, Energy Convers. Manage. 103 (2015)

16. A. Nemet, J.J. Klemes, Z. Kravanja, Energy 57 (2013)

17. M. Wzorek, M. Tańczuk, Waste Manage. Res. 33, 7 (2015)

18. J. Kalina, J Energy Convers. Manage. 51 (2010)

19. Energy Regulatory Office, http://www.ure.gov.pl/en/ 2017 [accessed 15 May 2017]. 